\title{
Editorial
}

\section{Publish or perish?}

M

any of you will be aware of the new and revised guidelines for promotions in various cadres, as specified by the Medical Council of India (MCI). It not only affects present and future promotions to the post of Associate Professor and Professor, but has been applied retrospectively for past promotions as well. The criteria laid down by the MCI specify.

1. Indexing agencies: Scopus, PubMed, Medline, Embase/Excerpta Medica, Index Medicus and Index Copernicus

2. Type of article which will be only considered: Original Research articles and Original research papers

3. National/international journal, provided it is published by the national society, and provided it meets the indexing criteria

4. Authorship: First or second author only

5. E journals are now accepted, as per revised circular of June 2016.

Luckily, the number of articles needed is not too much, 2 for promotion to Associate Professor and 4 for promotion to Professor, of which 2 must be in the tenure of Associate Professor.

What does this mean, and how will it affect journal publication in general?

Case reports, letters, points of view, review articles and ideas and innovations will therefore not be considered as fulfilling requirements. Does that mean we should do away with them? Not at all, since there is many a lesson to be learnt from a rare case, and many an extension of an idea.

Our peers and seniors developed many innovative techniques which have now become gold standards in treatment. Some of them were not tried before, and owing to the period of regulation (orlack of it), were able to develop these. Not so any more. Nowadays every paper has to be rigidly scrutinised, for clearance by the institutional review board, for patients' consent and general conformance to ethical publishing. Trials have become scarce, because of the huge compensation that has to be meted out, in case of any adverse effect, or worse, whether it is directly or not at all due to any medication or placebo which is part of the trial. These rigid pre conditions are designed to protect the patients' rights, but suddenly medical writing has taken a severe beating. Even animal experiments have severe curtailing regarding them, and more and more cell lines are being developed merely to test, in vitro, the effect of medications on various tissues.

The immediate consequence of these rather harsh guidelines, has been the burgeoning of several 'predator' or paid journals, which accept payment for publishing an article, using the $\mathrm{MCI}$ guidelines. In fact on their homepage, they display prominently that it fulfils $\mathrm{MCl}$ criteria.

Being a responsible editor of a journal published by the national society, which has made a presence for itself, it naturally causes some heartburn when articles are published in these "predator" journals, but we have to look at it from a practical point of view. We have to accept that our initial goals are to secure promotions, and do whatever it takes to ensure this. However, please remember, that is not the end. Medical reporting is a continuing process of medical education, and it is very unlikely that these ' predator' journals will be ever cited. Even during formal interviews for various positions, not only the number of publications, but also the nature of the journal is taken into consideration.

My message to you, especially the young and upcoming Plastic Surgeons, is, not to lose heart. I admit that the review process is fairly stringent and discriminative. As long as there is no bias, or unnecessary harshness, the editorial board usually does not interfere in the process. However, we are always here to protect your rights and dignity as an author. We are planning to streamline the review process and are hoping more reviewers come on board, so that no reviewer is taxed beyond measure. We are also looking at access to non open access articles from top journals, to assist the reviewers.

To conclude, if you have to submit to lesser well known journals, for the sake of meeting the requirements, 
please do so if you think it is necessary. The editor in me screams against it, but practicality deems it a necessary evil. However, once you have fulfilled the criteria, please turn your attention back to publishing in reputed journals, even though the process may be a bit more tedious. We owe it to our community to get our best ideas and thoughts in a forum which is widely read.

\section{Mukund Jagannathan \\ Editor IJPS, Professor and Head, Department of Plastic Surgery, LTM Medical College, LTMG Hospital, Sion, Mumbai, Maharashtra, India E-mail: editor@ijps.org}

This is an open access article distributed under the terms of the Creative Commons Attribution-NonCommercial-ShareAlike 3.0 License, which allows others to remix, tweak, and build upon the work non-commercially, as long as the author is credited and the new creations are licensed under the identical terms.

\begin{tabular}{|l|l|}
\hline \multicolumn{2}{|c|}{ Access this article online } \\
\hline Quick Response Code: & Website: \\
\hline & www.ijps.org \\
\cline { 2 - 2 } & \\
\hline
\end{tabular}

How to cite this article: Jagannathan M. Publish or perish?. Indian J Plast Surg 2017;50:1-2. 